\title{
Unusual record of a multiple predation of the Patagonian seahorse Hippocampus patagonicus by the Narrownose smooth-hound Mustelus schmitti in Argentine coastal waters
}

\author{
Mauro Belleggia ${ }^{1,2,3}$, María G. Pujol ${ }^{4}$, María L. Estalles ${ }^{5}$, Daniel E. Figueroa ${ }^{2,6}$ and \\ Diego C. LuZzatTo ${ }^{6}$ *
}

${ }^{1}$ Instituto Nacional de Investigación y Desarrollo Pesquero (INIDEP), Paseo Victoria Ocampo No 1, Escollera Norte, B7602HSA - Mar del Plata, Argentina. ${ }^{2}$ Laboratorio de Biología de Peces, Facultad de Ciencias Exactas y Naturales, Universidad Nacional de Mar del Plata (UNMdP), Funes 3350, B7602AYL - Mar del Plata, Argentina. ${ }^{3}$ Consejo Nacional de Investigaciones Científicas y Técnicas (CONICET), Argentina. ${ }^{4}$ Museo Municipal de Ciencias Naturales "Lorenzo Scaglia", Libertad 3099, B7600 - Mar del Plata, Argentina. ${ }^{5}$ Instituto de Formación Docente Continua - San Antonio Oeste, Islas Malvinas 1190, R8520 - San Antonio Oeste, Argentina. ${ }^{6}$ Instituto de Investigaciones Marinas y Costeras (IIMyC-CONICET), Facultad de Ciencias Exactas y Naturales, Universidad Nacional de Mar del Plata (UNMdP), Consejo Nacional de Investigaciones Científicas y Técnicas (CONICET), Argentina

\section{Marine and Fishery Sciences MAFIS}

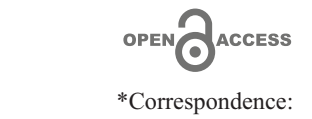

diegoluzzatto@conicet.gov.ar

Received: 9 December 2020 Accepted: 9 February 2021

ISSN 2683-7595 (print) ISSN 2683-7951 (online)

https://ojs.inidep.edu.ar

Journal of the Instituto Nacional de Investigación y Desarrollo Pesquero (INIDEP)

This work is licensed under a Creative Commons AttributionNonCommercial-ShareAlike 4.0 International License

\begin{abstract}
Seahorses (Genus Hippocampus) are rarely reported as prey items. Their low population numbers, their ability to blend with the environment and their low palatability are the features making them an unsuitable option for predators. Five individuals of the Patagonian seahorse Hippocampus patagonicus were found in the stomach of a single narrownose smooth-hound shark Mustelus schmitti from a sample of 959 stomachs analyzed. This rare record in a single stomach out of hundreds analyzed suggests that these individuals might have clustered in a group which was detected by the opportunistic M. schmitti.
\end{abstract}

Key words: Crypsis, diet, 'El Rincón', Syngnathidae, Triakidae.

Registro inusual de depredación múltiple del caballito de mar patagónico Hippocampus patagonicus por el tiburón gatuzo Mustelus schmitti en aguas costeras argentinas

RESUMEN. Los caballitos de mar (Género Hippocampus) raramente son reportados como presas. Su baja densidad poblacional, su habilidad para confundirse entre su entorno y su baja palatabilidad son características que los hacen una opción poco atractiva para depredadores. Cinco individuos del caballito de mar patagónico Hippocampus patagonicus fueron encontrados en un único estómago del análisis de una muestra de 959 estómagos del tiburón gatuzo Mustelus schmitti. Este inusual registro en un solo estómago de los cientos analizados sugiere que los caballitos de mar se encontraban agrupados cuando fueron detectados por el tiburón de hábitos oportunistas M. schmitti.

Palabras clave: Cripsis, dieta, "El Rincón”, Syngnathidae, Triakidae.

Sharks often play a role in the transfer of energy between trophic levels within marine ecosystems. The diet composition of sharks has been studied in order to understand the natural history of a particular species, their role in marine ecosystems, the impact of shark predation on economically valuable or endangered prey, among other reasons (Wetherbee and Cortés 2004). 
On their side, seahorses are rarely found as prey items (Kleiber et al. 2011). Morphological and ecological characteristics might contribute to predator avoidance. These species exhibit a remarkable capacity to be cryptic, they can change their coloration pattern and some species have long skin filaments or encrusting organisms on the skin enabling them to blend with their environments. They can remain virtually immobile for a long time and occur at low densities, which further complicates their localization (Foster and Vincent 2004). Their bony plates, spines and low energetic value make them an unpalatable option for predators. In addition, in all the cases recording seahorses as prey items, the predator has opportunistic and generalist habits (Kleiber et al. 2011).

The Narrownose smooth-hound Mustelus schmitti (Springer, 1939) is an opportunistic and generalist benthic mesopredator. Its diet varies along geographical locations and ontogeny and it is mainly composed of fishes, crabs, isopods, polychaetes, and mollusks (Belleggia et al. 2012). The geographical range of this shark largely overlaps with that of the Patagonian seahorse Hippocampus patagonicus Piacentino and Luzzatto 2004 (Figure 1 A). Both species inhabit the coastal areas of the Southwestern Atlantic Ocean extending from Rio de Janeiro ( $22^{\circ} \mathrm{S}$, Brazil). However, their southern limit differs. While M. schmitti extends as south as Ria Puerto Deseado $\left(47^{\circ} 45^{\prime} \mathrm{S}\right.$, Argentina) mainly at depths below $140 \mathrm{~m}$ (Chiaramonte and Pettovello 2000), H. patagonicus extends up to Puerto Madryn ( $42^{\circ} 47^{\prime} \mathrm{S}$, Argentina) and has been described as occupying patches in restricted areas at low depths mainly $<20 \mathrm{~m}$ (Piacentino and Luzzatto 2004; Luzzatto et al. 2012; Silveira et al. 2014).

The Narrownose smooth-hound is the shark most commonly caught by Argentinean fleets (Sánchez et al. 2012). Heavy exploitation over its entire geographical range (including nursery areas), its decreasing biomass, declines in landings, and reduction of size at first breeding have all led to this species being considered Critical Endangered by the International Union for Conservation of Nature (IUCN) Red List (Pollom et al. 2020). The Patagonian seahorse is also a threatened species and it is catalogued as Vulnerable due to habitat degradation and overexploitation (Wei et al. 2017). The present study reports and describes a rare record of a multiple predation of the seahorse $H$. patagonicus by the shark M. schmitti.

Sharks analyzed were collected during six bottom-trawl research cruises conducted by the research vessels 'Doctor Eduardo L. Holmberg', 'Capitán Cánepa', and 'Capitán Oca Balda' as part of a study led by the Instituto Nacional de Investigación y Desarrollo Pesquero (INIDEP) during 2008-2011 (Belleggia 2012). These research cruises were performed using a random stratified sampling scheme (stratified on latitude and depth; Figure 1 B). Surveys have been regularly conducted by INIDEP in order to estimate abundance. Fishing was conducted during daylight hours (07:00-19:00), at 3 to 4 knots for 30 min at each sampling site using an Engel bottom trawl (200 $\mathrm{mm}$ mesh in the wings, $103 \mathrm{~mm}$ in the cod end, $4 \mathrm{~m}$ vertical opening and $15 \mathrm{~m}$ horizontal opening). As part of a trophic ecology study, we undertook research into the diet of M. schmitti by sampling 959 individuals. Specimens of $M$. schmitti were sexed and total length (TL) was measured to the nearest $\mathrm{mm}$ from tip of the snout to the posterior end of the dorsal caudal lobe in its natural position. Maturity stage was recorded according to Walker (2005) and Colonello et al. (2011). Stomachs were excised, frozen and analyzed at the laboratory.

Prey items were identified to the lowest possible taxonomic level, counted and weighed to the nearest $0.01 \mathrm{~g}$. Diet composition was quantified for each prey by calculating the percentage frequency of occurrence $(\% \mathrm{~F}$, total number of stomachs in which a given prey was found expressed as percentage of total number of stomachs with food $)$, the percentage by number $(\% \mathrm{~N}$, total num- 

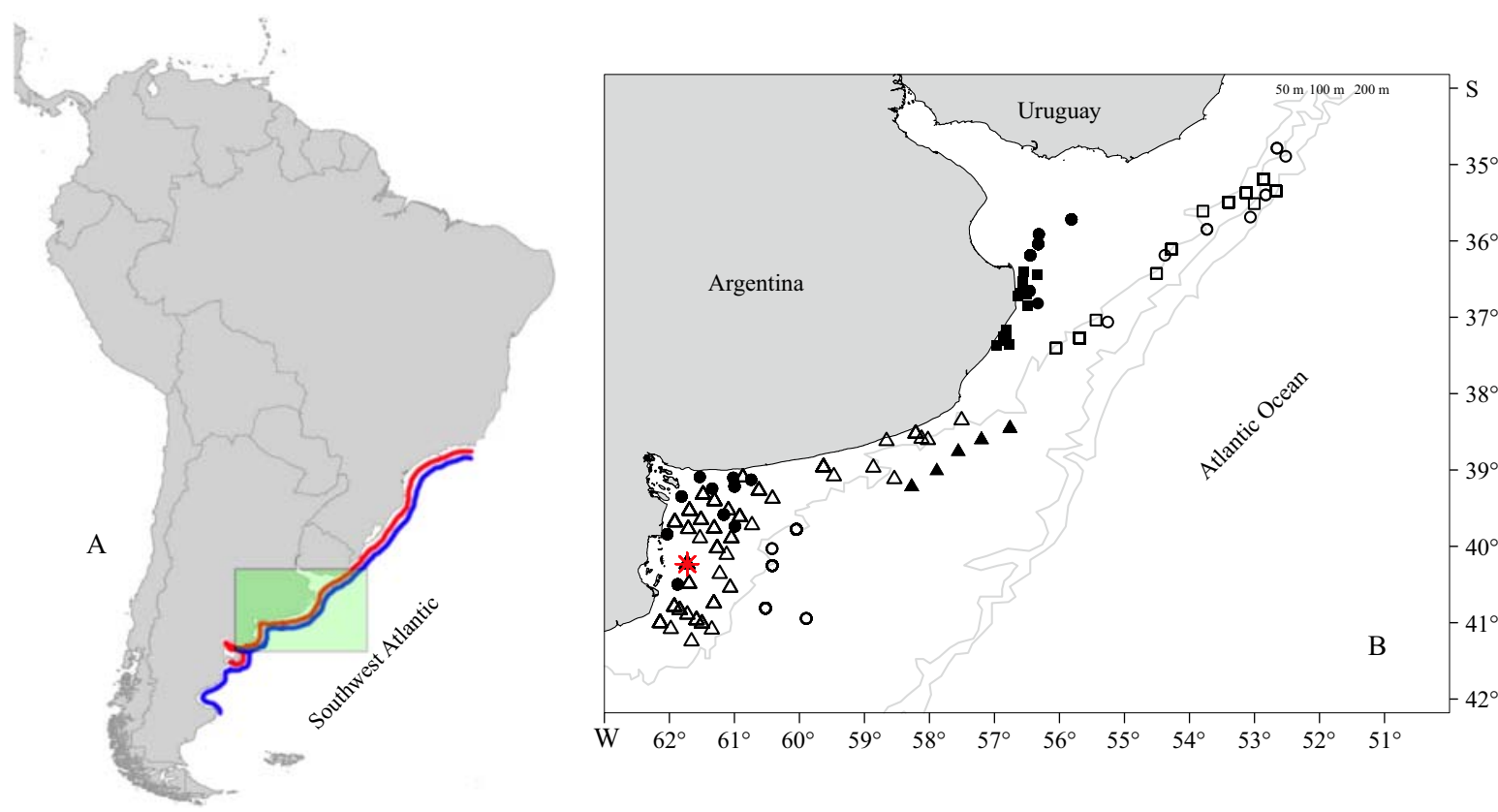

Figure 1. A) Geographical range of Mustelus schmitti (blue) and Hippocampus patagonicus (red) in the Southwestern Atlantic. Green square represents the study area. B) Study area indicating the position of bottom trawl samplings per date: October 2008 open dots, November 2008 bold dots, May 2009 open squares, September 2010 bold squares, April 2011 open triangles, June 2011 bold triangles. Red asterisk indicates the sampling site (40.139 $\mathrm{S}-61.436^{\circ} \mathrm{W} ; 20 \mathrm{~m}$ depth) where the specimen of M. schmitti presenting five individuals of $H$. patagonicus in its stomach was recorded.

ber of a given prey as percentage of total number of prey found), percentage by mass $(\% \mathrm{M}$, mass of a given prey as percentage of total mass of prey found) and index of relative importance: IRI = $\% \mathrm{~F} \times(\% \mathrm{~N}+\% \mathrm{M})($ Pinkas et al. 1971), expressed as a percentage (\%IRI; Cortés 1997).

A M. schmitti mature male of $652 \mathrm{~mm}$ TL and $1,052 \mathrm{~g}$ weight caught on research cruise 'Capitán Oca Balda' in 'El Rincón' area $\left(40.139^{\circ} \mathrm{S}\right.$ $61.436^{\circ} \mathrm{W} ; 20 \mathrm{~m}$ depth) in April 2011 (Figure 1 B) contained five individuals of $H$. patagonicus in different stages of digestion in its stomach. One of the seahorses remained almost intact, allowing several morphological measurements (Figure 2 A). Another individual was partially digested and some measurements were performed (Figure 2 B). Both individuals were deposited in the Syngnathid Collection of the Museum of Natural History 'Lorenzo Scaglia' (MMPEAA) (Table 1). The other three individuals were inferred by fragments of their tails and thoraxes. No morphological measurements could be performed on them.

Out of 959 specimens of M. schmitti analyzed and 944 (98.43\%) containing prey items, only one contained seahorses. According to the indexes estimated to quantify the diet composition of M. schmitti, percentage of frequency of occurrence $(\% \mathrm{~F})$ of seahorses in the diet was 0.01 , percentage by number $(\% \mathrm{~N})$ was 0.05 , percentage by weight $(\% \mathrm{~W})$ was 0.02 , and percentage of index of relative importance $(\% \mathrm{IRI})$ was $<0.001$. Together with the five seahorses identified, this stomach also contained other frequent prey items for $M$. schmitti: shrimp Artemesia longinaris (Bate, 1888) (0.04 g), brachyuran crabs Armases rubripes Rathbun, 1897 (0.13 g) and Collodes rostratus Edwards, 1878 (1.31 g, $14 \mathrm{~mm})$, and seven polychaetes of the families Ampharetidae $(0.33 \mathrm{~g})$ and Onuphidae $(0.21 \mathrm{~g})$. 

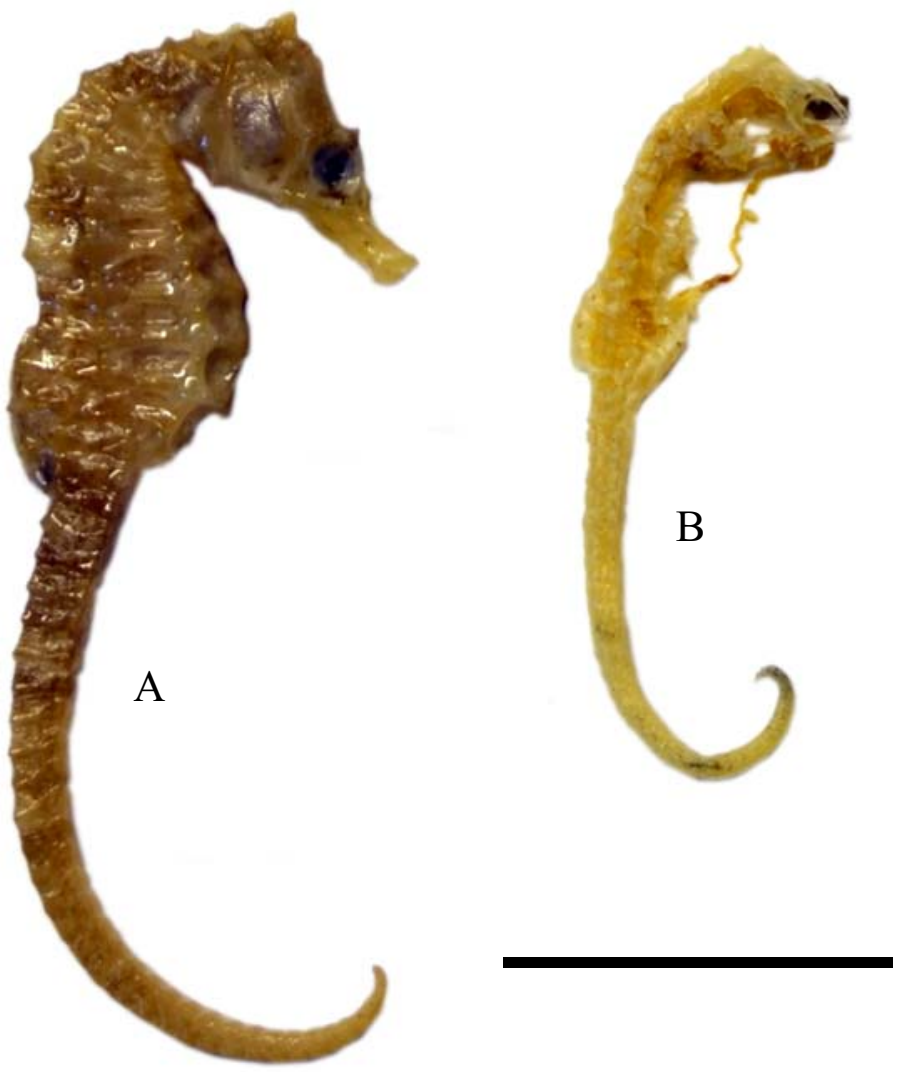

Figure 2. Measurable individuals of Hippocampus patagonicus obtained from the stomach of Mustelus schmitti. MMPEAA 36 (A) and MMPEAA 49 (B). Scale bar indicates $2 \mathrm{~cm}$.

The record of patches of $H$. patagonicus at shallow and intermediate depths $(0-20 \mathrm{~m})$ along the coastal area of north Patagonia and Buenos Aires Province and its record at deep waters (60 $\mathrm{m})$ in the Uruguayan and Argentine Common Fishing Zone (Luzzatto et al. 2012, 2014) indicated the presence of seahorses over a large depth range. Juvenile specimens of $H$. patagonicus drifting attached to floating debris or swimming freely may interconnect the patches and facilitate their ability to disperse to deep waters (Luzzatto et al. 2013). The record presented here together with that provided by Estalles et al. (2017) near Monte Hermoso allow to infer the presence of the species in an extended coastal area (Figure $1 \mathrm{~B}$ ).

As it was indicated above, M. schmitti is an opportunistic mesopredator shark. Its teeth are similar in shape, arranged in semi-pavement like crushing plates dentition, which makes it possible for them to eat crabs, gastropods, bivalves and other species protected by hard carapaces (Belleggia et al. 2014). Bony plates, spines and other morphological features of seahorses do not seem to make them an unpalatable option for the shark. However, this finding is the first record of seahorses in the diet composition of a Mustelus spp.

The predation event reported here is in line with the general findings of seahorses as prey items: their presence in the diet composition of marine predators is infrequent and mainly consisted of a single record. The presence of more than one seahorse individual in a single stomach is even rarer (Kleiber et al. 2011). The presence of five seahorses in a single stomach out of hun- 
Table 1. Morphological measurements of the predated seahorses deposited in the syngnathid collection of the Museum of Natural History 'Lorenzo Scaglia' (MMPEAA).

\begin{tabular}{lrc}
\hline & MMPEAA 36 & MMPEAA 49 \\
\hline Height (mm) & 74 & 50 \\
Tail length (mm) & 46 & 27 \\
Trunk length (mm) & 15 & - \\
Head height (mm) & 9 & - \\
Head length (mm) & 13 & - \\
Postorbital length (mm) & 3 & - \\
Snout length (mm) & 6 & - \\
Dorsal fin base (mm) & 7 & 4 \\
Pectoral fin base (mm) & 3 & - \\
Dorsal fin rays & 18 & $18-19$ \\
Pectoral fin rays & 12 & - \\
Anal fin rays & 4 & $11-12$ \\
Trunk rings & 11 & $38-39$ \\
Tail rings & 38 & \\
\hline
\end{tabular}

dreds analyzed suggests that these individuals might have clustered in a group that was detected by the opportunistic $M$. schmitti.

INIDEP contribution no 2240.

\section{REFERENCES}

BellegGia M. 2012. Ecología trófica del gatuzo, Mustelus schmitti (Springer, 1939) en el Mar Argentino [PhD thesis]. Mar del Plata: Facultad de Ciencias Exactas y Naturales, Universidad Nacional de Mar del Plata. 228 p.

Belleggia M, Figueroa DE, Bremec C. 2014. The dentition of the narrownose smoothhound shark, Mustelus schmitti. Mar Fresh Res. 65: 688-696.

Belleggia M, Figueroa DE, SÁnchez F, BreMEC C. 2012. The feeding ecology of Mustelus schmitti in the southwestern Atlantic: geographic variations and dietary shifts. Environ Biol Fish. 95: 99-114.
Chiaramonte GE, Pettovello AD. 2000. The biology of Mustelus schmitti in southern Patagonia, Argentina. J Fish Biol. 57: 930942.

Colonello JH, Christiansen EH, Macchi GL. 2011. Escala de madurez sexual para peces cartilaginosos de la Plataforma Continental Argentina. In: WöHler OC, Cedrola P, Cousseau MB, editors. Contribuciones sobre biología, pesca y comercialización de tiburones en la Argentina. Aportes para la elaboración del Plan de Acción Nacional. Buenos Aires: Consejo Federal Pesquero. p. 115-128.

CORTÉs E. 1997. A critical review of methods of studying fish feeding based on analysis of stomach contents: application to elasmobranch fishes. Can J Fish Aquat Sci. 54: 726-738.

Estalles ML, Pujol MG, Sánchez NE, Díaz de Astarloa JM, Luzzatto DC. 2017. The presence of the Patagonian seahorse Hippocampus patagonicus Piacentino and Luzzatto, 2004 (Teleostei: Syngnatidae) in Monte Hermoso, southwestern Buenos Aires province, Argenti- 
na. Check List. 13: 2065.

Foster S, VinCENT ACJ. 2004. Life history and ecology of seahorses: implications for conservation and management. J Fish Biol. 65: 1-61.

Kleiber D, Blight LK, CAldwell IR, Vincent ACJ. 2011. The importance of seahorses and pipefishes in the diet of marine animals. Rev Fish Biol Fish. 21: 205-223.

Luzzatto DC, Estalles ML, Díaz de Astarloa JM. 2013. Rafting seahorses: The presence of juvenile Hippocampus patagonicus in floating debris. J Fish Biol. 83: 677-681.

Luzzatto DC, Pujol MG, Figueroa D, Díaz DE ASTARLOA JM. 2014. The presence of the seahorse Hippocampus patagonicus in deep waters: additional evidence of the dispersive capacity of the species. Mar Biod Rec. 7: 1-2.

Luzzatto DC, Sieira R, Pujol MG, Díaz DE AstarloA JM. 2012. The presence of the seahorse Hippocampus patagonicus in the Argentine Sea based on the Cytochrome b sequence of mitochondrial DNA. Cybium. 36: 329-333.

Piacentino GLM, Luzzatto DC. 2004. Hippocampus patagonicus sp. nov., nuevo caballito de mar para la Argentina (Pisces, Syngnathiformes). Rev Mus Arg Cienc Nat ns. 6: 339349.

Pinkas LM, Oliphant S, IVerson ILK. 1971. Food habits of albacore, blue fin tuna and bonito in Californian waters. Cal Dep Fish Game. 152: 1-105.
Pollom R, Barreto R, Charvet P, Chiaramonte Ge, Cuevas JM, Herman K, MontealeGRe-Quijano S, Motta F, PAesch L, Rincon, G. 2020. Mustelus schmitti. The IUCN Red List of Threatened Species 2020: e.T60203A 3092243.

SÁnchez RP, NAVArro G, Rozycki V. 2012. Estadísticas de la pesca marina en la Argentina. Evolución de los desembarques 1898-2010. 1st ed. Buenos Aires: Ministerio de Agricultura, Ganadería y Pesca de la Nación.

Silveira RB, Siccha-Ramirez R, Santos Silva JR, Oliveira C. 2014. Morphological and molecular evidence for the occurrence of three Hippocampus species (Teleostei: Syngnathidae) in Brazil. Zootaxa. 3861: 317-332. doi:10.11646/zootaxa.3861.4.2

WALKER TI. 2005. Reproduction in fisheries science. In: HAMLETT WC, editor. Reproductive biology and phylogeny of chondrichthyes: sharks, rays and chimaeras. Enfield: Science Publishers. p. 81-127.

Wei J, Estalles ML, Pollom R, Luzzatto DC. 2017. Hippocampus patagonicus. The IUCN Red List of Threatened Species 2017: e.T195100A54909767.

Wetherbee BM, Cortés E. 2004. Food consumption and feeding habits. In: CARRIER JC, Musick JA, Heithaus MR, editors. Biology of sharks and their relatives. CRC Press. p. 225-246. 